\title{
Optimizing real-time PCR method to detect Leptospira spp. in human blood and urine specimens
}

\author{
Anis Karuniawati, Andi Yasmon, Ika Ningsih \\ Department of Microbiology, Faculty of Medicine, Universitas Indonesia, Jakarta, Indonesia
}

\begin{abstract}
Abstrak
Latar belakang: Leptospirosis adalah penyakit infeksi akut yang dapat menyerang manusia yang disebabkan bakteri Leptospira spp. dan digolongkan sebagai zoonosis. Gejala klinis leptospirosis yang tidak spesifik dan sulitnya uji laboratorium untuk konfirmasi diagnosis mengakibatkan penyakit ini seringkali tidak terdiagnosis. Oleh karenanya perlu dilakukan optimasi uji diagnostik molekuler menggunakan real-time PCR sebagai deteksi cepat Leptospira patogen yang sensitif dan spesifik. Penelitian ini di disain untuk mengoptimatisasi uji diagnostik molekuler menggunakan real time-PCR sebagai metode yang sensitif dan spesifik untuk mendeteksi Leptospira.
\end{abstract}

Metode: DNA bakteri di dalam spesimen diektraksi menggunakan DNA extraction kit dengan prosedur sesuai dengan petunjuk manualnya. Primer dan probe yang digunakan berdasarkan penelitian terpublikasi terdahulu. Penelitian ini menggunakan mesin PCR-IQTM5, iCycler Multicolor real-time PCR detection system. Spesifisitas primer diuji menggunakan DNA bakteri patogen lain yang mungkin dapat ditemukan pada kedua spesimen dan dapat memberikan gejala klinis yang mirip.

Hasil: Hasil uji real-time PCR menunjukkan bahwa kadar DNA Leptospira spp. terendah yang dapat terdeteksi adalah $0,375 \mathrm{fg} / \mu \mathrm{l}$. Hasil uji juga menunjukkan bahwa primer yang digunakan untuk deteksi bakteri Leptospira spp. tidak beraksi silang dengan genom bakteri uji lainnya. Konsentrasi minimal DNA bakteri standar yang masih dapat dideteksi dengan pemeriksaan ini adalah $150 \mathrm{fg} / \mu \mathrm{l}$, sedangkan dalam urin adalah $1470 \mathrm{fg} / \mu \mathrm{l}$.

Kesimpulan: Uji real-time PCR adalah metode yang cepat dan akurat untuk deteksi Leptospira spp. patogen pada spesimen manusia. Penelitian lebih lanjut diperlukan untuk mengetahui sensitivitas dan spesifisitas dari uji real-time PCR dibandingkan dengan metode diagnostik lain. (Med J Indones 2012;21:13-7)

\begin{abstract}
Background: Leptospirosis is an acute infectious disease in humans caused by Leptospira spp. and classified as a zoonosis. Clinical symptoms of leptospirosis are nonspecific and the current available laboratory method for detecting Leptospira spp. is difficult, which resulted to the misdiagnosis of this disease. Therefore, the rapid and accurate method is needed to diagnose the disease. This study was aimed to optimize molecular diagnostic test using real-time PCR assay as a rapid, sensitive and specific method for the detection of pathogenic Leptospira spp. in humans.

Methods: Bacterial DNA was extracted by DNA extraction kit according to the manufacturer's instructions. Primers and probes used in this study was based on previous and published research. The assay is performed using PCR-IQTM5, iCycler Multicolor real-time PCR detection system. Specificity of the primer used was evaluated towards some bacterial pathogens.

Results: Limit detection of the DNA was $0.375 \mathrm{fg} / \mathrm{ml}$ and the primers used does not cross-react with the genomes of the pathogens tested. Limit detection of DNA in blood is $150 \mathrm{fg} / \mu \mathrm{l}$, and in urine is $1470 \mathrm{fg} / \mu \mathrm{l}$.

Conclusion: Real-time PCR test is a rapid and accurate method for detecting pathogenic Leptospira spp. in human specimens. Further research is needed to determine the sensitivity and specificity of real-time PCR tests compared with other diagnostic methods in clinical settings. (Med J Indones 2012;21:13-7)
\end{abstract}

Keywords: Leptospirosis, Leptospira, optimization, real-time PCR

Leptospirosis is an acute infectious disease in human and animals caused by pathogenic Leptospira and classified as zoonosis. This disease remains a public health problem, especially in the tropics and sub-tropical with high rainfall and developing countries with poor hygienes. International Leptospirosis Society declared Indonesia as the country's high incidence of leptospirosis and ranked third in the world for mortality $(16.7 \%) .{ }^{1-4}$

Clinical symptoms of leptospirosis are nonspecific and the difficulty of laboratory tests to confirm diagnosis of this disease often lead to the delay or miss-diagnosis. The symptoms closely mimic malaria, dengue fever, hepatitis, meningitis, enteric fever and many other diseases characterized by fever, headache and myalgia..$^{3,7,10,11}$

There are some options of microbiological methods to support the diagnosis of leptospirosis, i.e direct examination to detect the presence of the bacteria or antigen such as culture, microscopy, PCR (Polymerase Chain Reaction) and indirect methods to detect antibodies 
to Leptospira, i.e microscopic agglutination test (MAT), enzyme linked immunosorbent assay (ELISA), and filtration test. ${ }^{3,5,6}$

Among those alternatives, detection of DNA is the most rapid, sensitive and specific method.,12 It can be performed by both methods, conventional and realtime PCR. In this study, we optimized the real-time Taqman PCR assay for early detection of Leptospira spp. in human specimen using universal primers based on the method developed by Smythe. ${ }^{5}$ The optimization is needed due to the use of different method of DNA extraction, reagents and PCR-machine.

\section{METHODS}

\section{Primers and probes}

Primers and probes used in this study based on research done by Smythe, ${ }^{5}$ and the rrs design based on gene sequences (16S) between 171 and 258 positions (87 bp product): LEP-patF CCCGCGTCCGATTAG 5'171 primer 3',LEP-primary patR 5'258TCCATTGTGGCCGRA/GACAC 3'PLep-patP. The probe is 5'205 (FAM) CTCACC-AAGGCGACGATCGGTAGC2283' (Tamra).

\section{Positive control}

DNA of the some pathogenic strains of Leptospira are obtained from DR. Rudy A Haartkeel Slotevart University, Amsterdam.

\section{DNA extraction}

DNA of Leptospira spp. was extracted using QIAamp DNA Mini Kit (Qiagen) and measured with NanoDrop (Thermo). The DNA is used as templates for the optimization of real-time PCR reaction.

\section{Optimizing the annealing temperature}

The optimization was done in the temperature range of $56-66^{\circ} \mathrm{C}$. Amplification carried out in $25 \mu \mathrm{l}$ PCR reaction-mix consisted of FastStart TaqMan probe master forward primer; reverse primer; probe with final concentration of $0.9 \mathrm{ng} / \mu \mathrm{l} ; 0.9 \mathrm{ng} / \mu \mathrm{l}, 0.2 \mathrm{ng} / \mu \mathrm{l}$, respectively, and $2 \mu \mathrm{l}$ of DNA. Each reaction is done in duplicate. PCR amplification process is performed in machine-IQTM5, iCycler multicolor real-time PCR detection system (Bio-Rad). Stages of amplification reaction consisted of denaturation at $95^{\circ} \mathrm{C}$ for 10 minutes, annealing at temperature range of $56-66^{\circ} \mathrm{C}$ for 1 minutes and elongation at $95^{\circ} \mathrm{C}$ for 15 seconds, in 45 cycles.

\section{Optimizing primer concentration}

The final concentration of primer used in this step are $0.45 \mathrm{ng} / \mu \mathrm{l}, 0.9 \mathrm{ng} / \mu \mathrm{l}, 1.35 \mathrm{ng} / \mu \mathrm{l}, 1.8 \mathrm{ng} / \mu \mathrm{l}, 2.25 \mathrm{ng} /$ $\mu 1$ and $2.7 \mathrm{ng} / \mu 1$. The annealing temperature used at this stage is the optimum temperature obtained in the previous step.

\section{Optimizing the probe concentration}

The final concentrations of probes used in this step are of $0.1 \mathrm{ng} / \mu 1,0.2 \mathrm{ng} / \mu \mathrm{l}, 0.3 \mathrm{ng} / \mu 1,0.4 \mathrm{ng} / \mu \mathrm{l}, 0.5 \mathrm{ng} / \mu \mathrm{l}$. The final concentration of primer used in this step is the one obtained in the previous step, i.e. $0.9 \mathrm{ng} / \mu \mathrm{l}$.

\section{Detection limit of DNA}

Distilled water solutions containing different concentration of DNA of some Leptospira strains are used to find the detection limit of DNA in the PCRreactions. The concentration was measured by a standard tool Thermo-Scientific Nano-Drop spectrophotometer.

\section{Specificity of PCR reaction}

Real-time PCR specificity was tested against DNA of some various pathogens: Streptococcus viridans, Pseudomonas aeruginosa ATCC 27853, Proteus mirabilis, Acinetobacter anitratus, Escherichia coli ATCC 25922, Salmonella typhi, Staphylococcus aureus ATCC 25923, Klebsiella pneumoniae, Serattia marcescens, Acinetobacter baumannii, Enterobacter aerogenes and Mycobacterium tuberculosis H37Rv.

\section{Detection limit of DNA in specimens}

Control DNA is inserted into the human urine and blood, which are known as negative Leptospira. The objectives of this simulation tests are to optimize the method of DNA extraction and to know the detection limit of DNA in each specimen.

\section{RESULTS}

Optimization of the real-time PCR reaction to detect the DNA of Leptospira was conducted in order to obtain ideal result. The primer pair used, as reported by Smythe, was designed based on RRS gene (16S) between 171 and 258 positions ( $87 \mathrm{bp}$ product) to detect all human pathogenic Leptospira spp. ${ }^{5}$

Leptospira spp. DNA was used as positive control during the optimization process. Eight (8) gradient of annealing temperature were conducted to find the best result, i.e. $56^{\circ} \mathrm{C}, 56.8^{\circ} \mathrm{C}, 58.1^{0} \mathrm{C}, 59.9^{\circ} \mathrm{C}, 60.4^{\circ} \mathrm{C}$, 


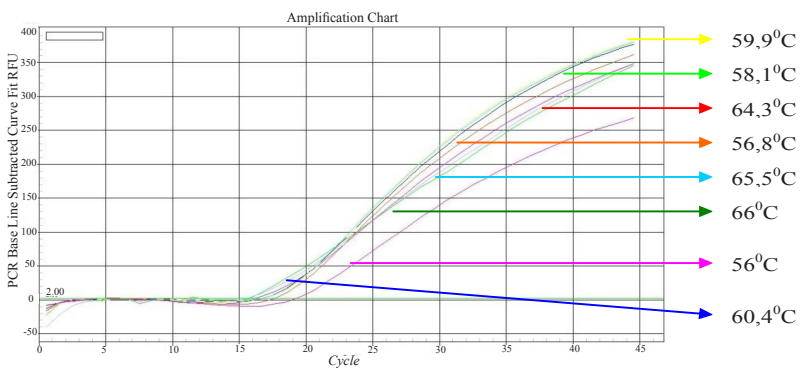

Figure 1. Result of the real-time PCR assay to optimize annealing temperature. Annealing temperature with the lowest threshold cycle is in the temperature range 58,10C-59,90C: 1. Yellow: 59,90C; 2. Light green: 58,10C; 3. Dark blue: 60,40C: 4.Orange: 56,80C; 5.Red: 64,30C; 6.Light blue: 65,50C; 7.Dark green: $660 C$; 8.Pink: 560C.

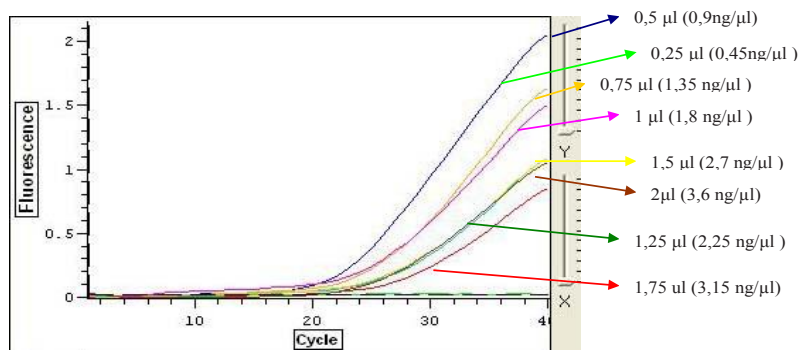

Figure 2. Result of the real-time PCR assay in optimizing the primer concentration. The optimal condition of the DNA amplification is performed using the primer concentration of 0,5 4 l (final concentration: $0,9 \mathrm{ng} / \mu \mathrm{l}$ ).

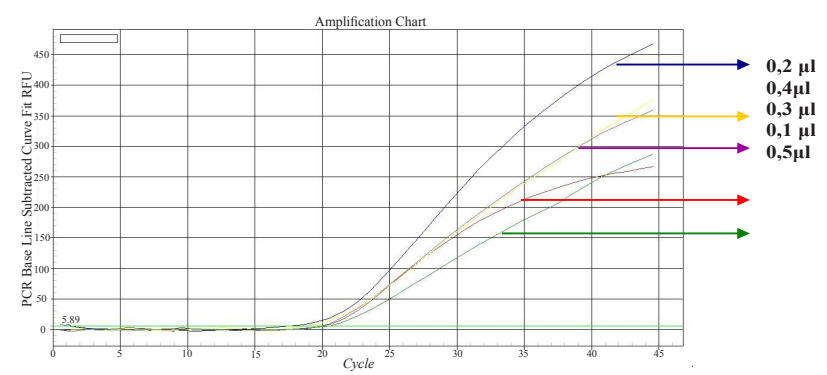

Figure 3. Result of the real-time PCR assay in optimizing the probe concentration. The optimal condition of the DNA amplification is performed using the probe concentration of 0,2 $\mu \mathrm{l}$ (final concentration: $0,2 \mathrm{ng} / \mu \mathrm{l}$ ).

$64.3^{\circ} \mathrm{C}, 65.5^{\circ} \mathrm{C}, 66^{\circ} \mathrm{C}$, using a PCR machine-IQTM5, icycler multicolor real-time PCR detection system (Bio$\mathrm{Rad})$. The result in Figure 1 showed that the optimal annealing temperature for the amplification is $59.9^{\circ} \mathrm{C}$ $\left(\approx 60^{\circ} \mathrm{C}\right)$. This temperature is then used to optimize the further step of $\mathrm{PCR}$ reaction.

Forward and reverse primers with different final concentrations were conducted, i.e. $0.45 \mathrm{ng} / \mu 1,0.9 \mathrm{ng} /$ $\mu 1,1.35 \mathrm{ng} / \mu 1,1.8 \mathrm{ng} / \mu 1,2.25 \mathrm{ng} / \mu \mathrm{l}$ and $2.7 \mathrm{ng} / \mu \mathrm{l}, 3.15$ $\mathrm{ng} / \mu \mathrm{l}$ and $3.6 \mathrm{ng} / \mu \mathrm{l}$. Figure 2 shows us that the final concentration of $0.9 \mathrm{ng} / \mu \mathrm{l}$ gave the optimal result.

The final concentrations of probes used in this step are of $0.1 \mathrm{ng} / \mu 1,0.2 \mathrm{ng} / \mu \mathrm{l}, 0.3 \mathrm{ng} / \mu 1,0.4 \mathrm{ng} / \mu 1,0.5 \mathrm{ng} / \mu \mathrm{l}$.

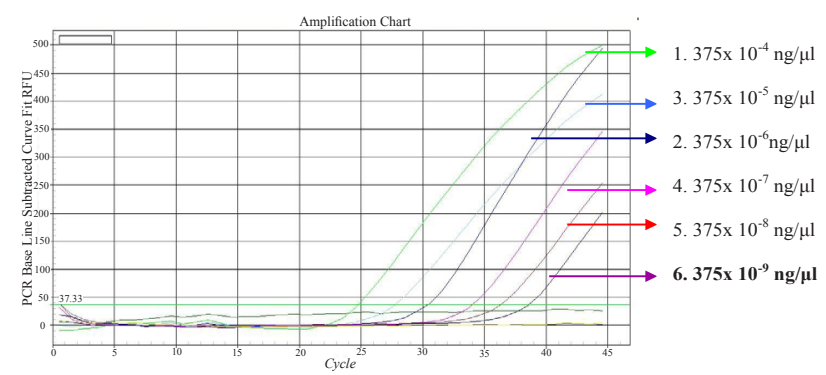

Figure 4. DNA sensitivity test of the real-time PCR assay. Different concentrations of DNA were applied in the PCR Mastermix Mix: 1. Green: $375 \times 10-4 \mathrm{ng} / \mu \mathrm{l} ; 2$. Light blue: $375 \times 10-5 \mathrm{ng} / \mu \mathrm{l} ; 3$.

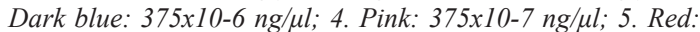

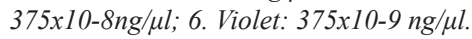

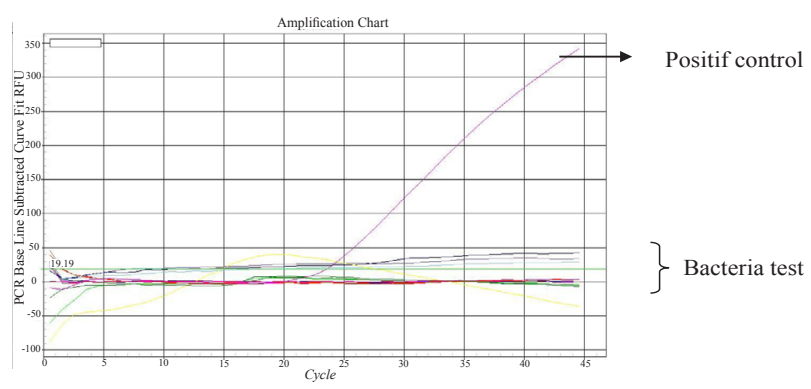

Figure 5.DNA specificity test of the real-time PCR assay. The assay seemed not to detect the DNA of other pathogenic bacteria: Streptococcus viridans, Pseudomonas aeruginosa ATCC 27853, Proteus mirabilis, Acinetobacter anitratus, Escherichia coli ATCC 25922, Salmonella typhi, Staphylococcus aureus ATCC 45923, Klebsiella pneumoniae, Serattia marcescens, Acinetobacter baumanii, Enterobacter aerogenes and Mycobacterium tuberculosis $H 37 R$ v.

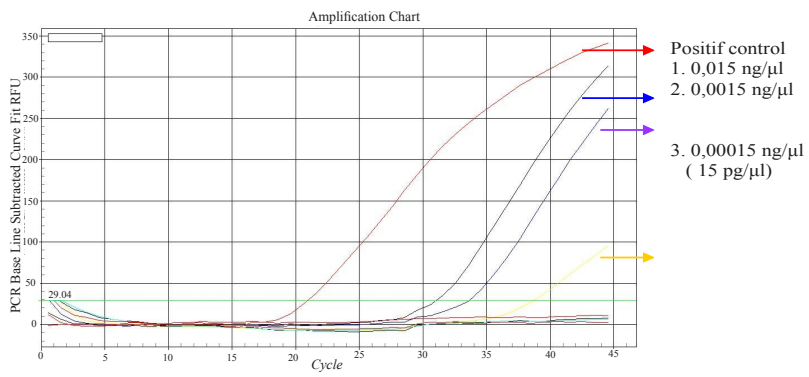

Figure 6. DNA sensitivity test of the real-time PCR assay in human blood specimen. Different concentrations of DNA were applied in the blood specimen: Red: positive control; 1. Blue: 0,015 ng/ $\mu \mathrm{l} ; 2$. Violet:0,0015 $\mathrm{ng} / \mu \mathrm{l}$; 3. Yellow: 0,0015 $\mathrm{ng} / \mu \mathrm{l}$.

Figure 3 shows that the best result was obtained when the final concentration of $0.2 \mathrm{ng} / \mu \mathrm{l}$ was used.

Detection limit of DNA in this real-time PCR reaction reached $375 \times 10^{-9} \mathrm{ng} / \mu 1$ or $0.375 \mathrm{fg} / \mu \mathrm{l}$ (Figure 4 ). The specificity of DNA was tested against some pathogen that might be found in urine and blood. Bacteria used were Streptococcus viridans, Pseudomonas aeruginosa ATCC 27853, Proteus mirabilis, Acinetobacter anitratus, Escherichia coli ATCC 25922, Salmonella typhi, Staphylococcus aureus ATCC 45923, Klebsiella pneumoniae, Serratia marcescens, 
Acinetobacter baumannii, Enterobacter aerogenes and Mycobacterium tuberculosis H37Rv. The reaction results shows that the primers used for the detection of Leptospira spp. bacteria do not cross-react with the genomes of these bacteria (Figure 5).

After all the condition of reactions were obtained, we did further reactions to know the detection limit of DNA in blood and urine specimen, which are known as negative Leptospira. We found that detection limit of DNA in human blood specimen is $150 \mathrm{fg} / \mu \mathrm{l}$ (Figure 6), and in urine is $1470 \mathrm{fg} / \mu \mathrm{l}$.

\section{DISCUSSION}

Culture techniques to grow the bacteria or microagglutination test to detect antibodies are cumbersome and need several days to perform the result. In our study, PCR was shown to be a useful technique as a rapid and accurate method to diagnose leptospirosis.

It was observed that the annealing temperature of $60^{\circ} \mathrm{C}$ for 1 minute gave the optimal result as reported also by Smythe. ${ }^{5}$ While Fearnley ${ }^{13}$ in another research used annealing temperature of $55^{\circ} \mathrm{C}$ for 15 seconds. Temperature selection of $59.9^{\circ} \mathrm{C}\left(\approx 60^{\circ} \mathrm{C}\right)$ for annealing based on the $\mathrm{Ct}$ value (cycle threshold) and substrate signal (the starting point where the fluorescence is detected) among the tested temperature. Efficient amplification required temperature settings for specific primer annealing, when the temperature used is higher, it will cause failure of primer annealing at the complementary DNA template. When it is lower, the primer can be attached at the wrong place and increase the yield of non-specific amplification.

Our study found that the primer concentration of 0.9 $\mathrm{ng} / \mu \mathrm{l}$ performed an ideal reaction. Smythe ${ }^{5}$ used a primer concentration of $3 \mathrm{pmol} / \mu \mathrm{l}$; Levett ${ }^{2}$ used a primer concentration of $300 \mathrm{nM}$ and Fearnley ${ }^{13}$ used a primer concentration of $500 \mathrm{nM}$. The different primer concentrations obtained are due to different enzyme, total volume of reaction, probe concentration, and the molecular weight of primers used in this study. In the PCR reaction primer is important to initiate the reaction and determine the amount of amplified DNA.

To perform an ideal reaction, the final concentration of probe needed was $0.2 \mathrm{ng} / \mu 1$. In the study conducted by Smythe, ${ }^{5}$ the probe concentration used was $2 \mathrm{pmol} / \mu \mathrm{l}$. Some studies have proven that the use of probes as a marker is more specific than syber-green.

The specificity of the primer used to detect pathogenic Leptospira was proven, when we performed the reaction against some bacteria mentioned above. All PCR- reactions gave negative results. In the study conducted by Smythe ${ }^{5}$, the specificity of the same primer was also observed. The tested bacteria were Escherichia coli 10418, Escherichia coli 9001, Yersinia enterolitica, Shigella sonnei, Enterobacter aerogenes, Pseudomonas aeruginosa, Citrobacter freundii, Pseudomonas fluorescens, Proteus vulgaris, Klebsiella pneumonia, Alcaligenes faecalis, Salmonella sanford, Vibrio cholera, Pasteurella multocida, Salmonella dublin, Borrelia burgdorferi, Staphylococcus epidermidis, Staphylococcus aureus, Bacillus cereus, Enterococcus faecalis, Listeria seeligeri, and Listeria monocytogenes. All PCR-reactions using those bacteria gave also negative results. $^{5}$

Simulation tests using Leptospira negative blood and urine were conducted to know the detection limit of the DNA in both specimens. We found that detection limit of DNA in human blood specimen is $150 \mathrm{fg} / \mu \mathrm{l}$, and in urine is $1470 \mathrm{fg} / \mu \mathrm{l}$. Unfortunately we have not be able to calculate the correlation of these DNA concentration with the number of bacteria cells due the difficulties to grow the bacteria.

Real-time PCR is a fast and accurate method for detecting pathogenic Leptospira spp. in human specimens. Further research is needed to determine the sensitivity and specificity of real-time PCR in clinical settings.

\section{Acknowledgment}

This research was funded by Competitive Research Grant Universitas Indonesia 2010.

\section{REFERENCES}

1. Colagross-Schouten AM, Mazet JA, Gulland FM, Miller MA, Hietala S. Diagnosis and seroprevalence of leptospirosis in California sea lions from coastal California. J Wildl Dis. 2002;38:7-17.

2. Levett PN. Leptospirosis. Clin Microbiol Rev. 2001;14(2):296-326.

3. Departemen Kesehatan RI. Pedoman tatalaksana kasus dan pemeriksaan laboratorium leptospirosis di rumah sakit. Jakarta: Direktorat Jenderal Pemberantasan Penyakit Menular dan Penyehatan Lingkungan; 2003. p. 10-19. Indonesian.

4. Aslantas O. Determination of seroprevalence of leptospirosis in Cattle by MAT and ELISA in Hatay, Turkey. Turk J Vet Anim Sci. 2004;29:1019-24.

5. Smythe LD, Smith IL, Smith GA, Dohnt MF, Symonds ML, Barnett LJ, et al. A quantitative PCR (TaqMan) assay for pathogenic Leptospira spp. BMC Infect Dis. 2002;2:13.

6. Dohe VB, Pol SS, Karmarkar AP, Bharadwaj RS. Two test strategy for the diagnosis of leptospirosis. Bombay Hospital Journal. 2009;51(1):18-21.

7. Kusmiyati, Noor SM, Supar. Leptospirosis pada hewan dan manusia di Indonesia. Balai Penelitian Veteriner Bogor. Wartazoa. 2005;15:213-20. Indonesian.

8. Jacobs RA. International disease spirochetal. In: Tierney LM, editor. Current medical diagnosis and treatment. 34th ed. London: A Lange Medical Book; 1995. p. 1197-214. 
9. Wijayanti K. Penegakan diagnosa leptospirosis. Dexa Media. 2008;21(1):17-20. Indonesian.

10. Judarwanto W. Leptospirosis pada manusia. Cermin Dunia Kedokteran. 2009; 36(5):347-50. Indonesian.

11. Gasem MH. Gambaran klinik dan diagnosis leptospirosis pada manusia. Kumpulan simposium leptospirosis. Semarang: Badan Penerbit Universitas Diponegoro; 2002. p. 17-31. Indonesian.
12. Gravekamp CK, Van de Kemp H, Franzen M, Carrington D, Schoone GJ, Van Eys GJJM, et al. Detection of seven species of pathogenic leptospires by PCR using two sets of pimers. J Gen Microbiol. 1993;139:1691-700.

13. Fearnley C, Wakeley PR, Beltran JG, Dalley C, Williamson $\mathrm{S}$, Gaudie C, et al. The development of a real-time PCR to decect pathogenic Leptospira species in kidney tissue. Res Vet Sci. 2008;85:6-16. 